Wesel, F. van, Alisic, E., Boeije, H. Using qualitative evidence to optimize child PTSD treatment guidelines. Psychological Trauma: Theory, Research, Practice, and Policy: 2014, 6(5), 546-554

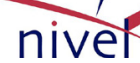

\begin{tabular}{|l|l|}
$\begin{array}{l}\text { Postprint } \\
\text { Version }\end{array}$ & 1.0 \\
\hline Journal website & http://psycnet.apa.org/index.cfm?fa=buy.optionToBuy\&uid=2013-45141-001 \\
\hline Pubmed link & $10.1037 / a 0035172$ \\
\hline DOI &
\end{tabular}

This is a NIVEL certified Post Print, more info at http://www.nivel.eu

\title{
Using Qualitative Evidence to Optimize Child PTSD Treatment Guidelines
}

\author{
FLORYT VAN WESEL (VU UNIVERSITY AMSTERDAM), EVA ALISIC (MONASH UNIVERSITY), \\ HENNIE BOEIJE (UTRECHT UNIVERSITY)
}

\begin{abstract}
The importance of patients' perspectives in the treatment of posttraumatic stress disorder (PTSD) is increasingly emphasized in recent years. However, qualitative evidence regarding these perspectives, is not systematically included in treatment guidelines. The possibilities of adding systematically aggregated recipients' views are examined in this paper, with a focus on children and adolescents. We reanalyzed a qualitative synthesis of the experiences of traumatized youth in order to derive recommendations for treatment. These recommendations were juxtaposed to 3 leading international sets of guidelines for children's treatment that stem from a quantitatively dominated evidence base. We found congruence between the 2 evidence bases regarding the broad impact of trauma, the importance of routines, and the involvement of parents in therapy. The yield of the qualitative synthesis comprised children's feeling of being both normal and different, their need for a vigorous posttrauma identity, the importance of building relationships with significant others, and the importance of providing children with something to "hold on to." The inclusion of both quantitative and qualitative sources of evidence holds the promise of better tailoring treatment to recipients' needs.
\end{abstract}

In the new Diagnostic and Statistical Manual of Mental Disorders (DSM-5), trauma is defined as exposure to actual or threatened death, serious injury, or sexual violation (American Psychiatric Association, in press). As many as 14\%-65\% of children experience a traumatic event during their childhood (Alisic, Van der Schoot, Van Ginkel, \& Kleber, 2008; Copeland, Keeler, Angold, \& Costello, 2007). Of these children, some develop posttraumatic stress disorder (PTSD), although most do not. This raises two important clinical questions: (a) What causes some children to develop PTSD and others not? and (b) How can we best treat children who have developed PTSD? The first question pertains to prevention of PTSD development, especially in vulnerable groups.

The second question addresses treatment options for those who have developed PTSD and their prospects, and is the focus of the current study. Therapy takes place in the relationship between mental health professionals and patients. In this article, we argue that psychological therapy can benefit from careful incorporation of 
Wesel, F. van, Alisic, E., Boeije, H. Using qualitative evidence to optimize child PTSD treatment guidelines. Psychological Trauma: Theory, Research, Practice, and Policy: 2014, 6(5), 546-554

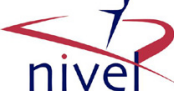

patients' views and experiences in treatment approaches and guidelines. Nowadays, how PTSD in children can best be treated is investigated not only through original studies but also through systematic reviews and meta-analyses (e.g., Stallard, 2006; Van Etten \& Taylor, 1998; Wethington et al., 2008). Based on the aggregation of the results of several individual studies, such summary studies give us an overview of the effectiveness of therapies. Examples of well-known child trauma treatments that are summarized in such a way are cognitive behavior therapy (CBT, e.g., Cohen, Berliner, \& Mannarino, 2000; Kowalik, Weller, Venter, \& Drachman, 2011) and eye movement desensitization and reprocessing (EMDR, Rodenburg, Benjamin, de Roos, Meijer, \& Stams, 2009).

In order to assist professionals, several guidelines have been developed on how to support, diagnose, and treat traumatized children (Cohen et al., 2010; Foa, Keane, Friedman, \& Cohen, 2008; United Kingdom National Institute for Health and Clinical Excellence guidelines, NICE, 2005). The guidelines differ in underlying methodology and contents. However, they are all built upon evidence of a quantitative nature; the included studies used quantitative data collection and data analysis techniques. When quantitative findings were not available, most often expert committees or opinions and experiences of authorities were used to discuss best practices (Forbes et al., 2010).

What seems to be underexposed in the evidence base so far are patients' opinions on, experiences with, and perceptions of the appropriateness of interventions. In line with the increasing focus on patient empowerment, NICE (NICE, 2005) describes the experiences of patients and carers in the context of the established guidelines. These experiences are thought to be important but are not yet systematically integrated in treatment guidelines. For example, the NICE guidelines on PTSD treatment refer to nine testimonies of "PTSD sufferers," all of whom are adults. Nine individual testimonies are specific, and provide less extensive and systematic information than the inclusion of syntheses of qualitative studies. In addition and not specific to PTSD treatment, several authors show that, although children "should be afforded the status as experts in their own experience with a fundamental right to contribute to their own mental health care," this is often not the case (Davies \& Wright, 2008, p.28). The inclusion of empirical qualitative research in this quantitatively dominated evidence base would facilitate the incorporation of real life experiences of recipients into evidence based policy making. An additional argument for including recipients' views in PTSD treatment guidelines is the assumption that, with (psychological) therapy taking place in a relationship between therapist and patient, the interaction is an important ingredient for therapy success.

Several studies stress the importance of the child-therapist alliance in cognitive behavior therapy for children with anxiety disorders (Chiu, McLeod, Har, \& Wood, 2009; Liber et al., 2010). The findings indicate that this alliance positively influences children's (mental) health outcomes (see also the meta-analysis by Karver, Handelsman, Fields, \& Bickman, 2006). Greater therapeutic alliance is also associated with greater therapeutic change, fewer perceived barriers, and greater treatment acceptability for children with behavior problems (Kazdin, Marciano, \& Whitley, 2005).

In-depth, qualitative methodologies are particularly suited to investigate children's views on therapy and the therapist. 
Wesel, F. van, Alisic, E., Boeije, H. Using qualitative evidence to optimize child PTSD treatment guidelines. Psychological Trauma: Theory, Research, Practice, and Policy: 2014, 6(5), 546-554

Collecting a combination of quantitative and qualitative data - so called mixed methods studies - has gained popularity over the past decades and practical guidance on how to integrate both strands is now widely available (e.g., Creswell \& Plano Clark, 2011; Morse \& Niehaus, 2009; Tashakkori \& Teddlie, 1998). Building on the success of primary mixed methods studies, in recent years, systematic review methodologists have developed several approaches for combining qualitative and quantitative evidence in reviews. For example, Thomas et al. (2004) examined the promotion of healthy food for children. They juxtaposed the results of a meta-analysis that measured effectiveness of interventions with the results of a qualitative synthesis that determined children's preferences. Another method, Bayesian meta-analysis, was used for studying immunization uptake (Roberts, Dixon-Woods, Fitzpatrick, Abrams, \& Jones, 2002). Other proposed approaches include synthesis of qualitative and quantitative evidence (Pope, Mays, \& Popay, 2007), Critical Interpretive Synthesis (Dixon- Woods et al., 2006), and Realist Synthesis (Pawson, Greenhalgh, Harvet, \& Walshe, 2004, 2005). Including therapy recipients' views in the evidence base underpinning the management of PTSD in children and adolescents may bring topics to light which are of particular importance for this specific target group and hard to grasp using quantitative effectiveness studies or expert opinions. In the present study we are interested in finding out if such topics exist and if they exist, what they contain. Such topics may be used to formulate additional guidelines. In order to investigate this potential yield of adding qualitative evidence - grounded in the recipients' views - to the existing evidence base of PTSD treatment in children, we use the matrix approach introduced by Thomas et al. (2004; EPPI-center), in which recommendations based on aggregated qualitative findings are juxtaposed to guidelines for treatment of PTSD originating in quantitative findings and expert opinions.

\section{METHOD}

\section{Qualitative Synthesis}

We used a recent synthesis of qualitative research on children's experience of being exposed to a traumatic event, the processing of the traumatic event and the factors influencing the recovery process.

This project is extensively discussed in van Wesel, Boeije, Alisic, and Drost (2011). Qualitative, English language, peer reviewed articles, published between January 1980 and September 2009 on the topic were searched by using five relevant electronic databases (PsycINFO, PubMed, EMBASE, PILOTS, and CINAHL) and by hand-searching seven relevant journals (Qualitative

Research, Journal of Mixed Methods Research, Trauma, Violence and Abuse, Traumatology, Clinical Child Psychology and Psychiatry, Transcultural Psychiatry, and Journal of Interpersonal Violence). As a result, a total of 17 articles investigating the experiences of children under the age of 19, who have worked their way through trauma were included in this synthesis. A description of the included studies can be found in Table 1. The quality of the included articles was appraised using a checklist and expert judgment (for an extensive description of this stage of the synthesis, see Boeije, Van Wesel \& Alisic, 2011). This quality appraisal did not lead to the exclusion of any of the 17 articles and is therefore not extensively reported here. 
Wesel, F. van, Alisic, E., Boeije, H. Using qualitative evidence to optimize child PTSD treatment guidelines. Psychological Trauma: Theory, Research, Practice, and Policy: 2014, 6(5), 546-554

The findings of the included studies were extracted and synthesized using thematic niver synthesis (Thomas \& Harden, 2008). This method for synthesizing qualitative studies involved three stages.

In stage one, we extracted the findings of the individual studies and coded them "line-byline." In the second stage, descriptive themes were developed based on this coding. The descriptive themes remained close to the primary studies. In the third and final stage, analytical themes were generated representing a stage of interpretation whereby the reviewers "go beyond" the primary studies and generate new interpretive constructs, explanations or hypotheses, in our synthesis endeavor represented by the categorization of the themes in three domains. We used NVivo9 software for the first stage of the analysis. For all stages, codes and results were discussed between at least two of the researchers and agreed upon.

See Table 2 for the three domains, the themes, and their descriptions.

The relations between the themes were synthesized as well (see van Wesel et al., 2011).

The aim of the original synthesis was to understand children's experience of being exposed to a traumatic event, the processing of the traumatic event and the factors influencing the recovery process.

Consequently, the focus of the analysis was on the event and on children's views and experiences. However, in the current study the review question was: "What are the parameters to adjust in fine-tuning the treatment of children suffering from PTSD according to this group?" For this review question, the focus of the analysis changed to children's needs and preferences relevant to treatment. As the review question changed we were forced to reanalyze the data (the findings in the articles). Therefore, we restructured the previously found codes and themes tailoring them to the needs of these youths. This analysis was conducted independently by two researchers (FW and $\mathrm{HB}$ ) and the results were discussed. In case of disagreement a third researcher (EA) was consulted. The findings as presented in the next section are a result of consensus between all researchers. Finally, we reformulated the findings into practical recommendations.

\section{[TABLE 1]}

\section{Guidelines}

We retrieved leading guidelines based on a publication by Forbes et al. (2010), who depicted a "guide to guidelines" for the treatment of PTSD. The authors defined a guideline as "systematically developed statements to assist practitioner and patient discussions about appropriate health care for specific clinical circumstances" (Field \& Lohr, 1990, p.38). Preferably, the evidence underlying these guidelines includes systematic reviews of high quality studies (i.e., randomized controlled trials). Because these are not always available, evidence stemming from other types of (systematically aggregated) quantitative studies is used in these guidelines as well. When no scientific studies are available, expert panels are used to provide lacking evidence.

Forbes et al. (2010) analyzed seven guidelines for clinical practice of PTSD and ASD. Three of the guidelines explicitly considered child and adolescent treatment: The United Kingdom National Institute for Health and Clinical Excellence (NICE) guidelines (NICE, 2005), The International Society for Traumatic Stress Studies (ISTSS) guidelines (Foa, Keane, Friedman, \& Cohen, 2008), and the American 
Wesel, F. van, Alisic, E., Boeije, H. Using qualitative evidence to optimize child PTSD treatment guidelines. Psychological Trauma: Theory, Research, Practice, and Policy: 2014, 6(5), 546-554

Academy of Child and Adolescent Psychiatry (AACAP) Practice Parameters for PTSD in Children and Adolescent (Cohen et al., 2010). Table 3 presents the guidelines proposed in these three documents. Note that this table only summarizes the key recommendations made by the authors of the guidelines and that more (extensive explanations of these) recommendations can be found in the full texts of these documents.

Furthermore, the final column of Table 3 shows what type of evidence supports each recommendation (as provided by the guidelines themselves). This evidence varies from controlled clinical trials to expert committees. This column was added for subsequent comparison with the recommendations based on the qualitative synthesis.

\section{[TABLE 2]}

\section{Analysis}

In order to investigate the yield of adding qualitative evidence to the existing evidence base, a matrix approach introduced by the EPPI-center (e.g., Candy, King, \& Oliver, 2011; Thomas et al., 2004) was used. For this approach the recommendations originating in the qualitative synthesis and the three sets of guidelines were juxtaposed. For each set of guidelines, two authors (FW and EA) investigated whether it explicitly included the qualitatively based recommendations and to what extent (partly or completely). By studying the appearing pattern, lacuna and overlap between the guidelines and recommendations could easily be detected.

\section{RESULTS}

\section{Qualitative Recommendations}

The recommendations from the 17 peer-reviewed qualitative studies were divided in three main areas: Trauma impact, Normalizing, and Support. The findings stemming from restructuring the original themes and their corresponding recommendations can be found in the first two columns of Table 4.

Trauma impact. The first area involves the actual trauma experiences a child lived through and how the child coped with those experiences. The first finding within this area involves the disruption of daily life due to the trauma. This disruption might involve the changes to the appearance of a child due to chemotherapy, a family member not being there anymore, or getting picked and nagged on by classmates. The finding shows that trauma can have a broad and extensive impact and that therefore the heart of the trauma needs to be traced. This forms the first recommendation. The second finding within this area is that the process of coping with traumatic experiences involves a continuous process of feeling normal, followed by feeling different, followed by feeling normal, and so forth. Children compared their pretrauma life with their posttrauma life. They saw how their lives, their friends, and their identities have changed. This leads to the recommendation of recognizing this process - normal-different - in several aspects of a child's life. Normalizing. The second area is concerned with getting things back to usual again. In the qualitative studies, children expressed their need to get their lives back on track again. For instance, they did not want to be treated as being different any more. They want to be just like any other child. Therefore, the qualitative evidence base recommends the reestablishment of old routines, such as going back to school as soon as possible and practicing sports. In order to reinstall these routines the 
Wesel, F. van, Alisic, E., Boeije, H. Using qualitative evidence to optimize child PTSD treatment guidelines. Psychological Trauma: Theory, Research, Practice, and Policy: 2014, 6(5), 546-554

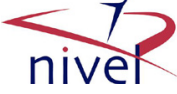

traumatic experiences need to be integrated in daily life, such that they become "normal," including learning how to regulate strong emotions (fear, anger, etc.). In addition, the children in the studies expressed the need to "be themselves again." Their posttrauma selves needed to get familiar to them. Many traumatized children suffered from low self-esteem, they saw the world and the people in it differently and they lost parts of their trust. Consequently, the recommendation is that clinicians and parents help children make the transition to a more vigorous posttrauma identity.

\section{[TABLE 3]}

Support. The third area includes all that has to do with feeling connected to significant others and having something to hold on to. First, the children expressed cherishing relationships with people with whom they could share their feelings and stories. These people may include parents, teachers, or friends from the hospital. The related recommendation is to support those meaningful relationships between children and significant others. A special role was assigned to the parents of a traumatized child. The presence of a caring parent, whether physical or emotional, appeared to be of great comfort, leading to the recommendation to involve parents in treatment, to educate them on how to raise a traumatized child, and to let them know that being present is important. Finally, the qualitative evidence showed that children needed to hang on to something. For some children this was a cuddly animal or other object, for other children this regarded religious or cultural aspects, or symbols. The associated recommendation is to comply with this need of getting grip and holding on to something.

\section{[TABLE 4]}

\section{Juxtaposing Recommendations and Guidelines}

The final column of Table 4 shows to what extent the three sets of international guidelines for PTSD treatment comply to the recommendations derived from the qualitative evidence base. A "Yes" indicates that a guideline complies completely with a recommendation, whereas "Partly" indicates that the intervention only partly complies with that recommendation. It should be noted that the focus of this analysis was on the explicit, key recommendations of the guidelines, not on the recommendations that may be mentioned in treatment manuals of the therapies proposed by the guidelines.

Table 4 shows that the NICE guidelines incorporate the least (2 "Yes," 1 _ "Partly" of the seven recommendations) of our recipient-based recommendations whereas the ISTSS guidelines incorporate most (2 _ "Yes," 3 _ "Partly" of 7). The AACAP guidelines comply fully with three out of seven recommendations but not with the remaining four. Especially in the area of Support, the recommendations and guidelines overlap considerably (3 _"Yes," 2 _ "Partly" of nine possibilities). It should also be noted that all guidelines involve helping to pick up old routines, requiring the integration of what happened and the regulation of strong feelings, and supporting and educating parents in raising a traumatized child. Overall, there is a substantial amount of overlap between the quantitatively based guidelines and the qualitatively based recommendations.

Lacuna can be found regarding children's identities. 
Wesel, F. van, Alisic, E., Boeije, H. Using qualitative evidence to optimize child PTSD treatment guidelines. Psychological Trauma: Theory, Research, Practice, and Policy: 2014, 6(5), 546-554

None of the guidelines mention the process of negotiating between being different and normal on several aspects of a child's life or guiding the child toward creating a vigorous posttrauma identity.

In addition, only one of the guidelines (NICE) recognized the importance of culture as something to hold on to for these children.

\section{CONCLUSIONS AND DISCUSSION}

In this study we investigated the yield of adding recipients' views to an existing, quantitatively driven evidence base in the treatment of PTSD in children and adolescents. The two sources of evidence conjoin on topics such as the importance of (a) recognizing that trauma can have a broad impact on a child's life, (b) picking up old routines or creating new ones, and (c) including parents in the treatment and giving them guidance on how to raise a traumatized child. This overlap is not surprising as (a) the existing evidence base is quite substantial, (b) the general tendency of both methodological frameworks is to consult existing literature to predefine important themes, (c) the fact that expert panels are used in creating the guidelines, and (d) Recommendations 1, 3, and 6 are prominent features of Traumafocused Cognitive Behavior Therapy (TF-CBT).

The two sources diverge with regard to the importance given to topics concerning a child's identity, such as them feeling different, creating a posttrauma identity, building relationships with significant others, and providing them with something to hold on to. This finding may have several reasons. Seen from a professional's perspective, recipients have far less attention for extinction of arousal symptoms through exposure (as this does not appear in the qualitative recommendations), although trauma experts appear to see it as one of the most active elements of trauma-focused therapy (Foa et al., 2008). It is well possible that it is more part of the professional knowledge of mental health clinicians while children are not aware of its diligence, and therefore do not report on it. It is of interest, however, that whereas the utility of exposure has been shown with adults, there is some controversy with respect to the necessity of exposure in the treatment of children. Recent findings show that cognitive therapy without exposure may be as effective as cognitive behavior therapy including exposure (Nixon, Sterk, \& Pearce, 2012). Seen from the recipients' perspective, themes such as identity are easily missed when using quantitative methods or expert clinicians' opinions. Although the importance of the topic of identity in relation to dealing with a shattered view of self, others, and the world has been emphasized by scholars such as Janoff-Bulman (1992), it apparently has not "made it" into the guidelines. Qualitative methods are par excellence appropriate for investigating such personal themes in a systematic way. It should be noted that the recommendations based on the qualitative data may be present in specific therapies rather than in the general guidelines. However, these recommendations are not accentuated in the guidelines as is indicated necessary by the recipients' views. Consequently, these issues may well be underexposed in the guidelines. This might be of particular importance to novice therapists. More experienced therapists may have learned about their clients' perspectives through their interactions over time. To gain a broad understanding of what their clients need and what their experiences are, novice therapists may benefit from more guidance. More coverage of qualitative findings may not only be relevant to clinicians but also to researchers; these findings can provide essential input into new quantitative 
Wesel, F. van, Alisic, E., Boeije, H. Using qualitative evidence to optimize child PTSD treatment guidelines. Psychological Trauma: Theory, Research, Practice, and Policy: 2014, 6(5), 546-554

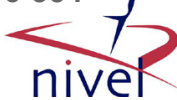

studies. As the guidelines are often drivers for new research (e.g., the ISTSS guidelines explicitly recommend areas for further study and discusses evidence gaps), both sources of current evidence should be included in this planning. The fact that only in the recent years qualitative research is being included in an evidence base is not surprising because it has been facing methodological challenges. However, methods have been developed for aggregating qualitative findings, pulling them out of their contextual nature and the quality of qualitative research has improved to a large extent over the past years. This study has shown that it can contribute unique insights to an existing evidence base. With this finding we follow the trend of including qualitative evidence in the evidence base as stressed by the Cochrane qualitative research methods group (Noyes, Popay, Pearson, Hannes, \& Booth, 2009). The yield of adding findings from a qualitative synthesis points to facets that are of importance to the recipients, although this does not necessarily imply that interventions that comply with the recipients' views are by definition more effective.

As a topic for further research, they may shed light on important aspects of therapy that contribute to therapy effectiveness. For example, qualitative research is well suited to inform us about the acceptability of treatment components, of ways that clients identify as enhancing compliance, and of factors that impact treatment dropout. The inclusion of both sources of evidence, quantitative and qualitative, in future guidelines holds an important promise to tailor treatment to recipients' needs.

\section{REFERENCES}

References marked with an asterisk indicate studies included in the qualitative synthesis.

Alisic, E., van der Schoot, T. A., van Ginkel, J. R., \& Kleber, R. J. (2008).

Looking beyond posttraumatic stress disorder in children: Posttraumatic stress reactions, posttraumatic growth, and quality of life in a general population sample. Journal of Clinical Psychiatry, 69, 1455-1461. doi: 10.4088/JCP.v69n0913_Al-Mashat, K., Amundson, N. E., Buchanan, M., \& Westwood, M.

(2006). Iraqi children's war experiences: The psychological impact of "Operation Iraqi Freedom". International Journal for the Advancement

of Counselling, 28, 195-211. doi:10.1007/s10447-006-9016-3 American Psychiatric Association. (in press). Diagnostic and Statistical

Manual of Mental Disorders (5th ed.). Arlington, VA: American Psychiatric Publishing.

Boeije, H. R., Wesel, F. van, \& Alisic, E. (2011). Making a difference: Towards a method for weighing the evidence in qualitative synthesis.

Journal of Evaluation in Clinical Practice, 17, 657-663. doi:10.1111/j.1365-

2753.2011.01674.x Candy, B., King, M., \& Oliver, S. (2011). Using qualitative synthesis to explore heterogeneity of complex interventions. BMC Medical Research

Methodology, 11, 124. doi:10.1186/1471-2288-11-124 Chiu, A. W., McLeod, B. D., Har, K., \& Wood, J. J. (2009). Child- therapist alliance and clinical outcomes in cognitive behavioral therapy for child anxiety disorders. Journal of Child Psychology and Psychiatry,

50, 751-758. doi:10.1111/j.1469-7610.2008.01996.x Cohen, J. A., Berliner, L., \& Mannarino, A. P. (2000). Treating traumatized children: A research review and synthesis. Trauma, Violence, and

Abuse, 1, 29-46. doi:10.1177/1524838000001001003 Cohen, J. A., Bukstein, O., Walter, H., Benson, R. S., Christman, A., Farchione, T. R., . . Medicus, J. (2010). Practice parameter for the assessment and treatment of posttraumatic stress disorder in children and adolescents. Journal of the American Academy of Child and Adolescent

Psychiatry, 49, 414-430.

_Coholic, D., Lougheed, S., \& Cadell, S. (2009). Exploring the helpfulness of arts-based methods with children living in foster care. Traumatology. 
Wesel, F. van, Alisic, E., Boeije, H. Using qualitative evidence to optimize child PTSD treatment guidelines. Psychological Trauma: Theory, Research, Practice, and Policy: 2014, 6(5), 546-554

Retrieved from http://tmt.sagepub.com/cgi/content/abstract/ 1534765609341590v Copeland, W. E., Keeler, G., Angold, A., \& Costello, E. J. (2007). Traumatic events and posttraumatic stress in childhood. Archives of General

Psychiatry, 64, 577-584. doi:10.1001/archpsyc.64.5.577 Creswell, J. W., \& Plano Clark, V. L. (2011). Designing and Conducting

Mixed Methods Research (2nd ed.). Thousand Oaks, CA: Sage.

Davies, J., \& Wright, J. (2008). Children's voices: A review of the literature pertinent to looked-after children's views of mental health services. Child and Adolescent Mental Health, 13, 26-31. doi:10.1111/ j.1475-3588.2007.00458.x_DeVoe, E. R., \& Smith, E. L. (2002). The impact of domestic violence on urban preschool children: Battered mothers' perspectives. Journal of

Interpersonal Violence, 17, 1075-1101. doi:10.1177/088626002236661 Dixon-Woods, M., Cavers, D., Agarwal, S., Annandale, E., Arthur, A., Harvey, J., . . Sutton, A. J. (2006). Conducting a critical interpretive synthesis of the literature on access to healthcare by vulnerable groups.

Medical Research Methodology, 6, 35. doi:10.1186/1471-2288-6-35_Earle, E. A., \& Eiser, C. (2007). Children's behaviour following diagnosis of acute lymphoblastic leukaemia: A qualitative longitudinal study.

Clinical Child Psychology and Psychiatry, 12, 281-293. doi:10.1177/ 1359104507075935

Field, M. J., \& Lohr, K. N. (1990). Clinical practice guidelines: Directions

for a new program. Washington, DC: National Academies Press.

Foa, E. B., Keane, T. M., Friedman, M. J., \& Cohen, J. (Eds.). (2008).

Effective treatments for PTSD: Practice guidelines from the International

Society for Traumatic Stress Studies (2nd ed.). New York, NY: Guilford Press.

Forbes, D., Creamer, M. C., Bisson, J. I., Cohen, J. A., Crow, B. E., Foa, E. F., . . Ursano, R. J. (2010). A guide to guidelines for the treatment of PTSD and related conditions. Journal of Traumatic Stress, 23, 537- 552. doi:10.1002/jts.20565_Forinder, U., \& Norberg, A. L. (2009). "Now we have to cope with the rest of our lives". Existential issues related to parenting a child surviving a brain tumor. Supportive Care in Cancer. Retrieved from http://www .springerlink.com/content/eq8w4I2870826722/ Hernandez, P., \& Romero, A. (2003). Adolescent girls in Colombia's guerrilla: An exploration into gender and trauma dynamics. Journal of

Prevention \& Intervention in the Community, 26, 21-38. doi:10.1300/ J005v26n01_03 Horowitz, K., McKay, M., \& Marshall, R. (2005). Community violence and urban families: $\bar{E}$ xperiences, effects, and directions for intervention.

American Journal of Orthopsychiatry, 75, 356-368. doi:10.1037/0002- 9432.75.3.356 JanoffBulman, R. (1992). Shattered assumptions: Towards a new psychology

of trauma. New York, NY: Free Press.

_Jones, L. (2002). Adolescent understandings of political violence and psychological wellbeing: A qualitative study from Bosnia Herzegovina.

Social Science \& Medicine, 55, 1351-1371. doi:10.1016/S0277- 9536(01)00275-1 Karver, M. S., Handelsman, J. B., Fields, S., \& Bickman, L. (2006).

Meta-analysis of therapeutic relationship variables in youth and family therapy: The evidence for different relationship variables in the child and adolescent treatment outcome literature. Clinical Psychology Review,

26, 50-65. doi:10.1016/j.cpr.2005.09.001 Kazdin, A. E., Marciano, P. L., \& Whitley, M. K. (2005). The therapeutic alliance in cognitive-behavioral treatment of children referred for oppositional, aggressive, and antisocial behavior. Journal of

Consulting and Clinical Psychology, 73, 726 -730. doi:10.1037/ 0022-006X.73.4.726

Kowalik, J., Weller, J., Venter, J., \& Drachman, D. (2011). Cognitive behavioral therapy for the treatment of pediatric posttraumatic stress disorder: A review and meta-analysis. Journal of Behavior Therapy

and Experimental Psychiatry, 42, 405- 413. doi:10.1016/j.jbtep.2011 .02.002 Liber, J. M., McLeod, B. D., van Widenfelt, B. M., Goedhart, A. W., van der Leeden, A. J. M.,. . . Treffers, P. D. A. (2010). Examining the relation between the therapeutic alliance, treatment adherence, and outcome of cognitive behavioral therapy for children with anxiety disorders. Behavior Therapy, 41, 172-186. doi:10.1016/j.beth.2009 .02.003 _Lustig, S. L., Weine, S. M., Saxe, G. N., \& Beardslee, W. R. (2004). 
Wesel, F. van, Alisic, E., Boeije, H. Using qualitative evidence to optimize child PTSD treatment guidelines. Psychological Trauma: Theory, Research, Practice, and Policy: 2014, 6(5), 546-554

Testimonial psychotherapy for adolescent refugees: A case series. Transcultural

Psychiatry, 41, 31-45. doi:10.1177/1363461504041352 Morse, J. M., \& Niehaus, L. (2009).

Principles and procedures of mixed

methods design. Walnut Creek, CA: Left Coast Press.

_Moscardino, U., Axia, G., Scrimin, S., \& Capello, F. (2007). Narratives from caregivers of children surviving the terrorist attack in Beslan: Issues of health, culture, and resilience.

Social Science \& Medicine, 64 ,

1776-1787. doi:10.1016/j.socscimed.2006.11.024 Nixon, R. D. V., Sterk, J., \& Pearce, A.

(2012). A randomized trial of cognitive behaviour therapy and cognitive therapy for children with posttraumatic stress disorder following single-incident trauma. Journal

of Abnormal Child Psychology, 40, 327-337. doi:10.1007/s10802-011- 9566-7 Noyes, J.,

Popay, J., Pearson, A., Hannes, K., \& Booth, A. (2009). Qualitative research and Cochrane reviews. In J. P. T. Higgins \& S.

Green (Eds.) The Cochrane Handbook for systematic reviews of interventions

(Chap. 20, pp. 571-592). New York, NY: Cochrane Collaboration/ Wiley-Blackwell.

Okundaye, J. N. (2004). Drug trafficking and urban African American youth: Risk factors for PTSD. Child \& Adolescent Social Work Journal,

21, 285-302. doi:10.1023/B:CASW.0000028456.32329.ea_Paton, J., Crouch, W., \& Camic,

P. (2009). Young offenders' experiences of traumatic life events: A qualitative investigation. Clinical Child

Psychology and Psychiatry, 14, 43-62. doi:10.1177/1359104508100135 Pawson, R., Greenhalgh, T., Harvet, G., \& Walshe, K. (2004). Realist

synthesis: An introduction. Manchester, UK: University of Manchester.

Pawson, R., Greenhalgh, T., Harvet, G., \& Walshe, K. (2005). Realist review: A new method of systematic review designed for complex policy interventions. Journal of Health Services Research and Policy,

10, 21-34. doi:10.1258/1355819054308530 Pope, C., Mays, N., \& Popay, J. (2007).

Synthesizing qualitative and

quantitative health evidence. A guide to methods. New York, NY: Open University.

Roberts, K. A., Dixon-Woods, M., Fitzpatrick, R., Abrams, K. R., \& Jones, D. R. (2002).

Factors affecting uptake of childhood immunisation: A Bayesian synthesis of qualitative and quantitative evidence. The Lancet,

360, 1596-1599. doi:10.1016/S0140-6736(02)11560-1 Rodenburg, R., Benjamin, A., de

Roos, C., Meijer, A. M., \& Stams, G. J.

(2009). Efficacy of EMDR in children: A meta-analysis. Clinical Psychology

Review, 29, 599-606. doi:10.1016/j.cpr.2009.06.008_Saldinger, A., Cain, A., \& Porterfield, K. (2003). Managing traumatic stress in children anticipating parental death. Psychiatry: Interpersonal

and Biological Processes, 66, 168 -181. doi:10.1521/psyc.66.2.168 .20613_Salter, E., \&

Stallard, P. (2004). Posttraumatic growth in child survivors of a road traffic accident. Journal of Traumatic Stress, 17, 335-340.

doi:10.1023/B:JOTS.0000038482.53911.01 Stallard, P. (2006). Psychological interventions for post-traumatic reactions in children and young people: A review of randomised controlled trials. Clinical Psychology Review, 26, 895-911. doi:10.1016/j.cpr.2005 .09.005

Tashakkori, A., \& Teddlie, C. (1998). Mixed methodology: Combining

qualitative and quantitative Approaches. Thousand Oaks, CA: Sage.

Thastum, M., Johansen, M. B., Gubba, L., Olesen, L. B., \& Romer, G.

(2008). Coping, social relations, and communication: A qualitative exploratory study of children of parents with cancer. Clinical Child

Psychology and Psychiatry, 13, 123-138. doi:10.1177/ 1359104507086345 Thomas, J., \& Harden, A. (2008). Methods for the thematic synthesis of qualitative research in systematic reviews. BMC Medical Research

Methodology, 8, 45-54. doi:10.1186/1471-2288-8-45 Thomas, J., Harden, A., Oakley, A., Oliver, S., Sutcliffe, K., Rees, R., ... .

Kavanagh, J. (2004). Integrating qualitative research with trials in systematic reviews. British Medical Journal, 328, 1010-1012. doi:10.1136/ bmj.328.7446.1010 UK National Institute for Health and Clinical Excellence (NICE). (2005). 
Wesel, F. van, Alisic, E., Boeije, H. Using qualitative evidence to optimize child PTSD treatmenk guidelines. Psychological Trauma: Theory, Research, Practice, and Policy: 2014, 6(5), 546-554

Guidelines National Institute for Health and Clinical Excellence. Retrieved from

http://www.nice.org.uk/Guidance/CG26_Urman, M. L., Funk, J. B., \& Elliott, R. (2001).

Children's experiences of traumatic events: The negotiation of normalcy and difference. Clinical

Child Psychology and Psychiatry, 6, 403-424. doi:10.1177/ 1359104501006003009 Van Etten, M. L., \& Taylor, S. (1998). Comparative efficacy of treatments for post-traumatic stress disorder: A meta-analysis. Clinical Psychology

Psychotherapy, 5, 126-144.

van Wesel, F., Boeije, H. R., Alisic, E., \& Drost, S. (2011). "l'll be working my way back:" a qualitative synthesis on the trauma experience of children. Psychological Trauma: Theory, Research, Practice, and Policy,

4, 516-526. doi:10.1037/a0025766 Wethington, H. R., Hahn, R. A., Fuqua-Whitley, D. S., Sipe, T. A., Crosby, A. E., Johnson, R. L., . . . Chattopadhyay, S. K. (2008). The effectiveness of interventions to reduce psychological harm from traumatic events among children and adolescents. A systematic review. American

Journal of Preventive Medicine, 35, 287-313. doi:10.1016/j.amepre .2008.06.024

Woodgate, R. L., \& Degner, L. F. (2003). A substantive theory of keeping the spirit alive: The spirit within children with cancer and their families.

Journal of Pediatric Oncology Nursing, 20, 103-119. 
Wesel, F. van, Alisic, E., Boeije, H. Using qualitative evidence to optimize child PTSD treatment guidelines. Psychological Trauma: Theory, Research, Practice, and Policy: 2014, 6(5), 546-554

\section{TABLES}

Table 1

Articles Included in the Qualitative Synthesis

\begin{tabular}{|c|c|c|c|c|}
\hline No. & Reference & Type of trauma & Sample & Method \\
\hline 1 & Al-Mashat et al. (2006) & War & 12 children & Data: Focus groups, drawings \\
\hline 2 & Coholic et al. (2009) & Chronic trauma & $\begin{array}{l}\text { Age: } 9-15 \\
38 \text { children } \\
20 \text { foster parents } \\
\text { Age: } 8-15\end{array}$ & $\begin{array}{l}\text { Analys1s: Focus groups } \\
\text { Data: Group session, interviews } \\
\text { Analysis: Constant comparison }\end{array}$ \\
\hline 3 & DeVoe \& Smith (2002) & Domestic violence & $\begin{array}{l}43 \text { mothers } \\
\text { Age: } 2-6\end{array}$ & $\begin{array}{l}\text { Data: Focus groups } \\
\text { Analysis: Modification of coding system }\end{array}$ \\
\hline 4 & Earle \& Eiser (2007) & $\begin{array}{l}\text { Diagnosis of Acute Lymphoblastic } \\
\text { Leukaemia }\end{array}$ & 32 mothers & Data: Semi-structured interviews \\
\hline 5 & Forinder \& Norberg (2009) & Brain tumor & $\begin{array}{l}\text { Age: } 1-14 \\
11 \text { parents } \\
\text { Age: } 7-14\end{array}$ & $\begin{array}{l}\text { Analysis: Thematic analysis } \\
\text { Data: Open-ended interviews } \\
\text { Analysis: Inductive thematic method }\end{array}$ \\
\hline 6 & $\begin{array}{l}\text { Hernandez \& Romero } \\
(2003)\end{array}$ & Combat exposure in guemilla & 7 children & Data: Semi-structured interviews \\
\hline 7 & Horowitz et al. (2005) & Community violence & $\begin{array}{l}\text { Age: } 13-17 \\
28 \text { children } \\
23 \text { parents } \\
\text { Age: } 8-17\end{array}$ & $\begin{array}{l}\text { Analysis: Constant comparison } \\
\text { Data: Focus groups } \\
\text { Analysis: Thematic coding }\end{array}$ \\
\hline 8 & Jones (2002) & War & 40 children & $\begin{array}{l}\text { Data: Interviews, story-writing, } \\
\text { participant observation }\end{array}$ \\
\hline 9 & Lustig et al. (2004) & War refugees & $\begin{array}{l}\text { Age: } 13-15 \\
3 \text { children } \\
\text { Age: } 17-18\end{array}$ & $\begin{array}{l}\text { Analysis: Grounded theory } \\
\text { Data: Narratives } \\
\text { Analysis: Unclear }\end{array}$ \\
\hline 10 & Moscardino et al. (2007) & Terrorism & $\begin{array}{l}17 \text { caregivers } \\
\text { Age: } 6-14\end{array}$ & $\begin{array}{l}\text { Data: Participant observation, semi- } \\
\text { structured interviews } \\
\text { Analysis: Thematic content analysis, } \\
\text { Code development }\end{array}$ \\
\hline 11 & Okundaye (2004) & Community violence & $\begin{array}{l}20 \text { children } \\
\text { Age: } 11-17\end{array}$ & $\begin{array}{l}\text { Data: Semi-structured interviews } \\
\text { Analysis: Topical and keyword recording }\end{array}$ \\
\hline 12 & Paton et al. (2009) & Traumatic life events (violence) & $\begin{array}{l}8 \text { children } \\
\text { Age: } 15-17\end{array}$ & $\begin{array}{l}\text { Data: Semi-structured interviews } \\
\text { Analysis: Interpretive phenomenological } \\
\text { analysis }\end{array}$ \\
\hline 13 & Saldinger et al. (2003) & Anticipated parental death & $\begin{array}{l}58 \text { children } \\
17 \text { parents } \\
\text { Age: } 6-16\end{array}$ & $\begin{array}{l}\text { Data: Semi-structured interviews } \\
\text { Analysis: Unclear }\end{array}$ \\
\hline 14 & Salter \& Stallard (2004) & Road traffic accidents & $\begin{array}{l}67 \text { children } \\
\text { Age: } 7-18\end{array}$ & $\begin{array}{l}\text { Data: Interview notes } \\
\text { Analysis: Framework technique }\end{array}$ \\
\hline 15 & Thastum et al. (2008) & Parental cancer & $\begin{array}{l}21 \text { children } \\
\text { Age: } 8-15\end{array}$ & $\begin{array}{l}\text { Data: Semi-structured interviews } \\
\text { Analysis: Descriptive phenomenological } \\
\text { method }\end{array}$ \\
\hline 16 & Urman et al. (2001) & Traumatic experiences & $\begin{array}{l}6 \text { children } \\
\text { Age: } 9-13\end{array}$ & $\begin{array}{l}\text { Data: Semi-structured interviews } \\
\text { Analysis: Grounded theory }\end{array}$ \\
\hline 17 & $\begin{array}{l}\text { Woodgate \& Degner } \\
\text { (2003) }\end{array}$ & Childhood cancer & $\begin{array}{l}39 \text { children } \\
\text { Age: } 4-18\end{array}$ & $\begin{array}{l}\text { Data: Focus groups, interviews, reflexive } \\
\text { journals, participant observation } \\
\text { Analysis: Constant comparison, illness } \\
\text { narrative inquiry }\end{array}$ \\
\hline
\end{tabular}

Table 2

Descriptions of Themes in Qualitative Child Trauma Research Arranged by Domain

\begin{tabular}{|c|c|}
\hline Theme & Description \\
\hline & Individual domain \\
\hline Feelings & Emotions that are directly linked to the traumatic event such as fear, anxiety, helplessness, loneliness and guilt. \\
\hline Trauma impact & $\begin{array}{l}\text { Secondary trauma and all consequences of the disruption of daily life such as the perceived sense of uncertain threat, } \\
\text { behavior resulting directly from the trauma, copy-cat behavior and taking refuge. }\end{array}$ \\
\hline Coping & Strategies used for dealing with trauma such as denial, acting tough, and taking control. \\
\hline Giving meaning & The process of reflecting upon what happened, including how the trauma is given a place in life. \\
\hline Identity & $\begin{array}{l}\text { How children see themselves, how they think and feel about themselves, their sense of self, self-esteem, self- } \\
\text { awareness, and knowing themselves. }\end{array}$ \\
\hline Current outlook & Traumatized children's views on the posttrauma-world and, in particular on their future development. \\
\hline Phases & $\begin{array}{l}\text { Several phenomena that develop in stages, for instance: aging of children, children's level of development, and the } \\
\text { processing of trauma through time. }\end{array}$ \\
\hline Normalcy & What used to be self-evident in daily life, includes looking normal, being like peers, and normal child behavior. \\
\hline Growth & Positive outcomes of a trauma experience such as the development of cognitive and emotional skills and maturation. \\
\hline Negotiation & The process of constant interchange between normalcy and difference because of the traumatic event happening. \\
\hline & Family domain \\
\hline Parenting & $\begin{array}{l}\text { The parents' observations of the child and their interference with the child, their relationship with the child and their } \\
\text { efforts in the raising of a child with trauma (such as taking away their worries, disciplining, listening, protecting, } \\
\text { and answering questions). }\end{array}$ \\
\hline Interpersonal relationships & Interaction of traumatized children with others, such as peers and acquaintances. \\
\hline & Community domain \\
\hline Support & All kinds of help given by family, friends, school, and the community in general. \\
\hline Culture & $\begin{array}{l}\text { The nature of the community in terms of cohesion and openness, as well as religious beliefs, and political and } \\
\text { ideological views. }\end{array}$ \\
\hline
\end{tabular}


Wesel, F. van, Alisic, E., Boeije, H. Using qualitative evidence to optimize child PTSD treatment guidelines. Psychological Trauma: Theory, Research, Practice, and Policy: 2014, 6(5), 546-554

Table 3

Guidelines for Treatment of PTSD in Children and Adolescents

\begin{tabular}{|c|c|c|}
\hline Guide & Guidelines & Evidence \\
\hline \multirow[t]{8}{*}{ NICE (2005) } & 1) Separately question child and carer about the presence of PTSD symptoms. & $\mathrm{D}$ \\
\hline & $\begin{array}{l}\text { 2) Inform carers briefly about the possibility of PTSD development and symptoms after the child experienced } \\
\text { a traumatic event (in emergency rooms). }\end{array}$ & $\mathrm{D}$ \\
\hline & $\begin{array}{l}\text { 3) Offer TF-CBT to children with severe posttraumatic symptoms or PTSD in the first month after the } \\
\text { traumatic event. }\end{array}$ & $\mathrm{C}$ \\
\hline & $\begin{array}{l}\text { 4) Offer TF-CBT to all children with PTSD adopted to suit their age, circumstances, and level of } \\
\text { development. }\end{array}$ & B \\
\hline & $\begin{array}{l}\text { 5) When appropriate involve family in the treatment of the child. Treatment focused on the carers alone is } \\
\text { unlikely to help reduce PTSD symptoms. }\end{array}$ & $\mathrm{C}$ \\
\hline & $\begin{array}{l}\text { 6) Duration of treatment normally 8-12 sessions. Treatment should be regular and continuous and delivered } \\
\text { by the same person. }\end{array}$ & $\mathrm{C}$ \\
\hline & 7) Drug treatment should not be routinely prescribed. & $\mathrm{C}$ \\
\hline & $\begin{array}{l}\text { 8) In considering treatment carers and children should be informed that apart from TF-CBT, no good } \\
\text { evidence exists for the efficacy treatments such as play therapy, art therapy, or family therapy. }\end{array}$ & $\mathrm{C}$ \\
\hline \multirow[t]{11}{*}{ AACAP (2010) } & $\begin{array}{l}\text { 1) Psychiatric assessment of children and adolescents should routinely include questions about traumatic } \\
\text { experiences and PTSD symptoms. }\end{array}$ & A \\
\hline & $\begin{array}{l}\text { 2) The clinician should conduct a formal evaluation to determine whether PTSD is present, the severity of } \\
\text { the symptoms, and the degree of functional impairment. Parents should be included in this evaluation } \\
\text { whenever possible. }\end{array}$ & A \\
\hline & 3) The assessment should consider differential diagnosis of other disorders that may mimic PTSD. & A \\
\hline & $\begin{array}{l}\text { 4) Treatment planning should consider an approach including the severity and degree of impairment of the } \\
\text { symptoms. }\end{array}$ & A \\
\hline & 5) Treatment planning should incorporate appropriate interventions for comorbid disorders. & A \\
\hline & $\begin{array}{l}\text { 6) Trauma focused psychotherapies should be considered first-line treatments (psycho-education, parenting } \\
\text { skills, relaxation skills, affective modulation skills, cognitive coping and processing, trauma narrative, in } \\
\text { vivo mastery of trauma reminders, conjoint parent-child sessions, enhancing future safety and } \\
\text { development). }\end{array}$ & A \\
\hline & 7) Selective serotonine reuptake inhibitors can be considered for treatment. & $\mathrm{C}$ \\
\hline & 8) Other medications should be considered for treatment. & $\mathrm{C}$ \\
\hline & 9) Treatment planning may consider school-based accommodations. & B \\
\hline & 10) Therapies that bind, restrict, withhold food or water, or are otherwise coercive are not endorsed. & $\mathrm{G}$ \\
\hline & $\begin{array}{l}\text { 11) School or community-based screening of PTSD symptoms and risk factors should be conducted after } \\
\text { traumatic events that affect a significant number of children. }\end{array}$ & B \\
\hline \multirow[t]{7}{*}{ ISTSS (2009) } & $\begin{array}{l}\text { 1) Cognitive Behavior Therapy is advised to be adapted to the individual child, including parental treatment, } \\
\text { psycho-education, relaxation and stress management, affective expression and modulation skills, cognitive } \\
\text { coping skills, trauma narrative, cognitive processing, in-vivo desensitization, conjoint child-parent session, } \\
\text { and enhancing safety and future development. Additional tenets: skills development provided prior to } \\
\text { exposure, parental inclusion in therapy, recognition of trauma impact, cultural adaptation possible. }\end{array}$ & A-B \\
\hline & $\begin{array}{l}\text { 2) Apply psycho-pharmacotherapy including: Serotonergic agents, Adrenergic agents, Dopaminergic agents, } \\
\text { when severe comorbid psychiatric issues are present, when severity of PTSD is interfering in engagement } \\
\text { of psychotherapy, or when there is no psychotherapy available. }\end{array}$ & A-F \\
\hline & 3) EMDR needs further research and is advised for cases of single trauma only. & B \\
\hline & $\begin{array}{l}\text { 4) School-based treatment including curricular interventions and school-based symptom treatment is advised } \\
\text { for reaching at-risk students and can be helpful in improving a broad range of a child's functioning. }\end{array}$ & B \\
\hline & $\begin{array}{l}\text { 5) Acute interventions can be used when seen fit, including: systematic approaches, Art and massage } \\
\text { therapies (not proven effective), EMDR, Debriefing (not proven effective), Cognitive Behavioral } \\
\text { approaches (not proven effective), and Psychological first Aid (not proven effective). More research is } \\
\text { needed. }\end{array}$ & $\mathrm{C}$ \\
\hline & $\begin{array}{l}\text { 6) Psychodynamic Therapy can be useful when a child's development is disrupted by the trauma. However, it } \\
\text { takes a lot of time and more research is needed. }\end{array}$ & A-B \\
\hline & $\begin{array}{l}\text { 7) Creative Arts Therapies can be used by experienced therapists, but care should be taken with concem to } \\
\text { retraumatization. }\end{array}$ & $\mathrm{C}$ \\
\hline
\end{tabular}

Note. $\mathrm{A}=$ randomized well controlled clinical studies; $\mathrm{B}=$ well conducted clinical studies; $\mathrm{C}=$ naturalistic clinical studies; $\mathrm{D}=$ recommended good practice; $\mathrm{E}=$ Expert committee; $\mathrm{F}=$ new development not tested; $\mathrm{G}=$ no evidence. 
Wesel, F. van, Alisic, E., Boeije, H. Using qualitative evidence to optimize child PTSD treatment guidelines. Psychological Trauma: Theory, Research, Practice, and Policy: 2014, 6(5), 546-554

Table 4

Findings, Corresponding Recommendations From Qualitative Synthesis, and Corresponding Compliance of International Treatment Guidelines

\begin{tabular}{|c|c|c|}
\hline Findings & Recommendations & Guidelines \\
\hline \multicolumn{3}{|l|}{ Trauma impact } \\
\hline $\begin{array}{l}\text { - Trauma is a disruption of daily life and concerns } \\
\text { the child, its parents and social environment }\end{array}$ & $\begin{array}{l}\text { 1. Trace the heart of the trauma, note that trauma can have } \\
\text { a broad and extensive impact }\end{array}$ & $\begin{array}{l}\text { NICE: Yes } \\
\text { AACAP: Yes } \\
\text { ISTSS: Yes }\end{array}$ \\
\hline $\begin{array}{l}\text { - Coping with trauma is a process of the continuous } \\
\text { interchange between being normal and being } \\
\text { different }\end{array}$ & $\begin{array}{l}\text { 2. Recognize the process of being different and normal on } \\
\text { several aspects of a child's life }\end{array}$ & $\begin{array}{l}\text { NICE: No } \\
\text { AACAP: No } \\
\text { ISTSS: No }\end{array}$ \\
\hline \multicolumn{3}{|l|}{ Normalizing } \\
\hline $\begin{array}{l}\text { - Children feel the need to continue with their daily } \\
\text { lives }\end{array}$ & $\begin{array}{l}\text { 3. Help picking up (old) routines. This requires integrating } \\
\text { what happened and regulating strong feelings }\end{array}$ & $\begin{array}{l}\text { NICE: Partial } \\
\text { AACAP: Yes } \\
\text { ISTSS: Partial }\end{array}$ \\
\hline - Children want to be themselves again & $\begin{array}{l}\text { 4. Guide the child towards creating a vigorous posttrauma } \\
\text { identity }\end{array}$ & $\begin{array}{l}\text { NICE: No } \\
\text { AACAP: No } \\
\text { ISTSS: No }\end{array}$ \\
\hline \multicolumn{3}{|l|}{ Support } \\
\hline $\begin{array}{l}\text { - Children cherish familiar relationships witch } \\
\text { people with whom they share things }\end{array}$ & $\begin{array}{l}\text { 5. Support healthy relationships with other people such as } \\
\text { peers, classmates, and teachers }\end{array}$ & $\begin{array}{l}\text { NICE: No } \\
\text { AACAP: No } \\
\text { ISTSS: Partial }\end{array}$ \\
\hline - The presence of parents is comforting for children & $\begin{array}{l}\text { 6. Support and educate parents in raising a traumatized } \\
\text { child. Emphasize on the importance of parental presence }\end{array}$ & $\begin{array}{l}\text { NICE: Yes } \\
\text { AACAP: Yes } \\
\text { ISTSS: Yes }\end{array}$ \\
\hline - Children are looking for things to hold on to & $\begin{array}{l}\text { 7. Give children something to hold on to. For example: by } \\
\text { establishing relationships, by providing cultural or } \\
\text { religious symbols, or by cuddly animals }\end{array}$ & $\begin{array}{l}\text { NICE: No } \\
\text { AACAP: No } \\
\text { ISTSS: Partial }\end{array}$ \\
\hline
\end{tabular}

Note. NICE = the UK National Institute for Health and Clinical Excellence guidelines; AACAP = the American Academy of Child and Adolecent Psychiatry Practice Parameters; ISTSS = the International Society for Traumatic Stress Studies guidelines. For compliance with the guidelines, "Yes" indicates complete compliance, "No" indicates a lack of explicit compliance, and "Partial" indicates partial compliance, all ordered by area. 